\title{
A Study of the Awareness of Property Managers and Other Built Environment Professionals on Sustainable Buildings in Kaduna Nigeria
}

\author{
Haruna. Dutse Bungwon ${ }^{1}$, Daniel.I.Dabo ${ }^{2}$, and David Ayock Ishaya ${ }^{3}$
}

\begin{abstract}
The roles that building plays in the modern society are as diverse and profound as the persons that uses them. It is important to recognize that buildings significantly impact human comfort, productivity, efficiency and the social legacy and the environmental footprint future generation will inherit The aim of the study was to find out the level of awareness of property managers and other built environment professionals on green or sustainable buildings ,using qualitative methods. the findings reveal Low level of awareness by property managers and other built environment professionals, also a lack of technological advancement .Negligence from the part of professional bodies to enlighten their members on now innovations in the construction industry. There is no expertise knowledge on what a green building is. Lack of interest from real estate developers.
\end{abstract}

Index Terms-Awareness. Building, Built Environment, Professional, Property Managers, Sustainable.

\section{INTRODUCTION}

Since early 1990s, sustainable construction or Green building has been widely accepted in construction industry. In 1999, the International Council for Research and Innovation in building and construction (CIB) published the agenda 21 on sustainable construction (1) which has clarified the main concepts, aspect and challenges that sustainable development present to civil construction.

To realize sustainable development in the construction industry, building environmental assessment methods, which are designed to promote environmental awareness amongst built environment professionals, have been perceived as effective tools. (2) define building environmental assessment methods as a tools for evaluating building performance with respect to broad range of environmental considerations, organized into assessment criteria.

Green building brings together a vast array of practices, techniques and skills to reduce and ultimately eliminate the impacts of buildings on the environmental and human health. It often emphasizes taking advantage of renewable resources, e.g. using sunlight through passive solar, active solar and using plant and trees through green roofs, rain garden and reduction of rain water run off. Many other techniques are used, such as using low

\footnotetext{
${ }^{1}$ Department of Building, College of Environmental Studies. Kaduna Polytechnic. Kaduna. Nigeria.

${ }^{2}$ Department of Quantity Surveying, College of Environmental Studies. Kaduna Polytechnic. Nigeria.

${ }^{3}$ Department of Estate Management, College of Environmental Studies. Hussaini Adamu Federal Polytechnic, Kazaure. Jigawa State. Nigeria
}

impact building materials or using packed gravels or permeable concrete instead of conventional concrete(3). The aim of the study was to find out the level of awareness of property managers and other built environment professionals on green or sustainable buildings, using qualitative methods. For the purpose of this study both green or sustainable buildings mean the same thing.

\section{StATEMENT OF PROBLEM}

There has been an increase in environmental pollution, which can be link to the use of building materials that are not environmental friendly nor sustainable in the long run. This Challenge to the environment and humans can be eradicated or minimized by the concept of sustainability. Green building is not a simple development trend; it is an approach to building suited to the demands of its time, whose relevance and importance will only continue to increase. The benefits to green cannot be overemphasized. Increase in property value, the low operating costs and easy maintenance of green building make for lower vacancy rates and higher property values.

\section{A. Research Questions}

1. What is the level of development of green or sustainable buildings in Kaduna?

2. What is the level of awareness of green building by the professionals and what is responsible for that level of awareness?

3. What are the benefits of green or sustainable buildings?

\section{B. Justification of the Study}

The awareness of property managers on green building and sustainability will be useful and helpful to both practitioners (Estate Surveyors and Valuers) and property development team alike(Architects, Builders, Quantity Surveyors, Town Planners and Land Surveyors) The findings will review some of the importance of green building and sustainability which will at long run enlighten the populace on the concepts and benefits of green or sustainable buildings.

\section{Literature Review}

(4) conducted research to answer the question on whether building assessment tools originated from developed countries could satisfy the different environmental focus and social economic needs. The study suggested that before using a universal green building assessment tool, it is necessary to analyze the local situation and identify the adaptability of using such a tool in a specific country and region. (5),identified the 
benefits of green roof. According to research by $(16,18)$, increasing advocacy and preemption to anticipated tightening standards have resulted in growing demand from property owners/developers and tenants for a greener building. Professional practicing in Nigeria today has limited knowledge, experience and expertise in sustainable design and construction. An earlier study by (7)published in the report of the International Research Conference on Sustainability in built environment in (2010), found that just over half $(54.5 \%)$ of those surveyed possessed some knowledge of green building and its benefit.

Nigeria may soon require a universally acceptable green building rating system adapted to suit local standards and environmental priorities. The Green Building Council of Nigeria (GBCN) will, in all likelihood, drive the development of such a system, which shall be expected to unify competing concerns and provide a single useful metric for establishing the relative greenest of a building. This should be beneficial to the professionals in the building industry to meet the sustainable development objectives. For example, requirement for implementing sustainability issues in property valuation, architect are being asked to provide sustainable designs while planners are promoting sustainable cities, engineers and builders are advocating sustainable construction $(7,8,17)$.

(9) concludes thus "The transition to sustainability is urgent because global life-support systems - the environment - has a time limit.

(11) observed that "Sustainability is a difficult concept for people to understand" studies by (12) noted that "there is a need to refine the decision making process for assessing sustainability applicable to the built environment the author also stress that "this involves integrating various aspects of sustainability rather than dealing with discrete element of the problem. (8) discuss the local development of sustainability indicators, the authors ended by saying "Sustainability indicators are principally about awareness raising and making environmental, economic and social sub-systems transparent to citizens and decision makers:

\section{Research Design}

The Purpose of the study(aim) should determine the research methods and techniques adopted in the research $(13,14)$. The study is exploratory in nature, which is most suitable in addressing the research questions(13).The target population was the Property Managers and the other built environment professionals who were selected using purposive sampling method, they include Architects, Builders, Quantity Surveyors, Town Planners, Land Surveyors. The names and addresses of the property managers and other built environment professional were obtained from the directory of the professional institutions Kaduna State branch directory. data was obtained using unstructured interview and focus group techniques, for more on qualitative research techniques and Focus group see(15)

\section{E. Data Presentation and Analysis}

The data collected from the survey are on the awareness of property managers and other built professionals on sustainable buildings in Kaduna

Level of Development of Green or Sustainable Buildings
All the Property Managers agreed that the implementation or adoption of sustainability in buildings is at an infant stage, a property managers said "Most investors are afraid of being the first to initiate such a move". Other built environment professionals were of the view that getting the skill man power for the whole life cycle of the buildings was a major challenge to its adoption.

Level of Awareness of Property Managers on Sustainable Buildings

In all 6 Property managers were involved in the focus group interview based on the set criteria by the researchers. Only 3 of the 6 property managers had a high level of awareness, the reason being that they were trained in England, and as members of RICS, they are regularly updated through CPD, the remaining 3 have a low level of awareness because they were not taught in school, neither do they understand the concept of green buildings. However, they read something about it, in journals.

\section{F. Benefits of Sustainable Buildings(Property Managers)}

The benefits of green buildings is in reducing running cost, which the property managers consider paramount, since the interest of the property owner is to maximized profits.

Level of Awareness of other Built Environment Professionals

In all 10 built professionals were interviewed, 2 each from the professions mentioned earlier.

The Builders had a high level of awareness of green buildings and some of its benefits, on whether there is green buildings in Kaduna, the answer was not clear, since they belief there is no $100 \%$ green building in Kaduna, except some features of green buildings are incorporated in to some buildings. The Quantity Surveyors had the next highest level of awareness of green buildings after the builders, it may be as a result of their exposure and involvement in conferences both at the national and international level, next is the Architect who are aware of green building with an equal level of understanding of the concepts of green buildings inspite of the fact that they are always involved in design of buildings, Town Planners are next on the level of awareness after the Architects, most of the town planners have knowledge, which they obtained from postgraduate studies, in the university. the Land Surveyors are the least aware of green building, this may be due to their little involvement in the fabric of the construction process besides setting out.

\section{G. Benefits of Green Buildings(other Built Environment Professionals)}

The benefits were numerous, these were however not far fetched from the functions perform by each professional. The builders see the benefits in term of ease of maintenance of the buildings at little cost, Use of renewable energy (e.g. maximum use of natural day lighting)Effective controls and building management system Use of energy efficient and eco-friendly equipment (e.g low energy consumption achieved by a range of techniques including the use of natural ventilation rather than air conditioning, heat recovering siphons, and the use of thermal mass, careful fabrication and low - energy lighting design) . the architects belief the benefit is in the beautification of the landscape, whilst the quantity surveyors belief the benefits of green buildings is, it will reduce the running cost in terms of 
repairs and Adoption of cost - effective and environmentally friendly technologies. the town planners see green buildings as promoting sanity of the planned environment and the use of non-toxic materials, minimizing site impact. on the part of the land surveyors they see it as bringing sanity in to the development process.

\section{FINDINGS}

Low level of awareness by property managers and other built environment professionals, also a lack of technological advancement .Negligence from the part of professional bodies to enlighten their members on now innovations in the construction industry. There is no expertise knowledge on what a green building is. Lack of interest from real estate developers. Although sustainable construction has been regarded as a good policy, the real estate developers, designers and contractors are only interesting if they can get more profit.

\section{RECOMMENDATION}

There should be wide public awareness on the importance and the benefit of green building. Also the Nigerian institution of Estate Surveyors and Valuers, Nigerian Institute of Architects, Nigerian Institute of Builders and the Nigerian institute of Quantity Surveyors, Nigerian institute of Town Planners, Nigerian Institute of Surveyors should enlighten their members on the importance and the benefit of green building. Also it should enlighten in the (MCPDs) and at the annual Nationals conferences so as to make their member aware of new challenges in the building industry. Therefore, to promote application of green building, the government should make compulsory policies and institutions which can ensure that sustainability is embedded into the basic construction and operation processes.

\section{CONCLUSION}

This study has been able to explore the level of awareness of green or sustainable buildings, with particular reference to Kaduna, Nigeria. which was low, besides the level of sustainable buildings, which is at it infant stage, Future research can possibly look at the barriers to green or sustainable buildings.

\section{REFERENCES}

[1] Andrew.D.(2008) Methodological Pluralism in Construction Management Research in Advanced Research Methods in The Built Environment Editors Andrew knight and les Ruddock, Blackwell Publishing West Sussex

[2] Bond A J. and Morrison-Saunders, A (2011) Re-Evaluating Sustainability Assessment: Aligning the Vision and the Practice. Environmental Impact Assessment Review 31(1), 1-7. http://dx.doi.org/10.1016/j.eiar.2010.01.007

[3] CIB, (1999). Agenda 21 on Sustainable Construction Report Publication 237, Rotterdam. .

[4] Dietz, S and Neumayer, E. (2007) Weak and Strong Sustainability in the SEEA: Concepts and Measurement. Ecological Economics, 61(4), 617-26.

http://dx.doi.org/10.1016/j.ecolecon.2006.09.007

[5] Institute of Ecology(2010)obafemi Awolowo University Ile Ife, International Research Conference on Sustainability in Built Environment ile-ife.Nigeria
[6] John, P., Moritz, L., James, C and Michael, M. (2012) Sustainability: How Stakeholder Perceptions differ from Corporate Reality University of California, Bertheley. 55(1), 74.

[7] Kruja and Hasaj (2010). Comparisons of Stakeholders Perception Towards the Sustainable Tourism Development and its Impacts in Stikodra Region (Albania)

[8] Lenz.M. (2006) What is Stopping Sustainable Building in England: Barriers Experienced by Stakeholders in Delivering Sustainable Development, Oxford Institute of Sustainable Development, School of Built Environment Oxford Brookes University, UK.

[9] Lozano. R. (2008). Envisioning Sustainability Three Dimensionally. Journal of Cleaner Production 16, 1838-46. http://dx.doi.org/10.1016/j.jclepro.2008.02.008

[10] Richard.F.. and Anita.L.(2003) Research Methods for Construction,2nd Edition, Blackwell Science.

[11] R. Hill, and Kats.G. (2002). Sustainable Building Assessment Method. Paper presented in International Conference on Sustainable Building

[12] Silverman.D.(2005) Doing Qualitative Research A Practical Handbook(2nd edition) Sage

[13] Susan .D and Ahadzie. J(2013) Barriers to Sustainable Construction in the Ghanian Construction Industry-Consultants Perspectives

[14] US Urban Environmental Institute, (2002). Resource Guide for Sustainable Development in Urban Environment.

Websites:

-Green building wikipedia,( www.wikipedia.org)Accesed on 23rd June,2014.

-U.S. Green Building Council(WWW.USGBC.ORG.GOV)Accesed on the 4th May ,2014.

(16)-Nigerian Green Building Council(www.NGBC.ORG.NG)Accesed on the $20^{\text {th }}$ April, 2014 